\title{
RELIABILITY OF MORTGAGE VALUATION FOR INSTITUTIONAL LENDING IN NIGERIA
}

\author{
Bioye Tąjudeen ALUKO \\ Department of Estate Management, Obafemi Awolowo University, Iie - Ife, Nigeria \\ Tel: + 234 (0) 803337 8674; E-mail: btaluko@yahoo.com
}

Received 5 April 2004; accepted 19 November 2004

\begin{abstract}
The growing number of distressed banks in Nigeria and the recognition of mortgage valuation as a measure of investment performance of collaterals to mitigate the risks of loan underwriting process necessitates this study. It examined whether open market valuations of mortgage properties were a good proxies for their sale prices. Pooled data, involving 121 open market sales during the period 1994 to 2002, on property transactions in the study area with their corresponding contemporaneous valuations were gathered from the estate surveying and valuation firms, the lending institutions and the Nigerian Deposit Insurance Corporation. The data emanating therefrom were analysed with the aid of multiple regression models. The study revealed, amongst other things, that open market valuation for mortgage is a good proxy for their transaction price in the study area; although, the accuracy is not as good as what obtains in U.K, U.S.A. and Australia.
\end{abstract}

KEYWORDS: Reliability; Mortgage valuation; Nigeria

\section{INTRODUCTION}

Availability of credit has been frequently described as the lifeblood of any real estate development. But, mortgage valuation is fundamental to bank lending decisions (Loveli and French, 1996). In secured lending, for example, the underlying philosophy is to assess the open market value of the assets on which the loan is based and to ensure that the former is greater than the amount borrowed. The degree by which the asset value exceeds the loan provides the margin of asset cover or the loan-to-value ratio (McWilliams, 1992; Crosby, French and Ward, 1993; Loveli and French, 1996; Baum, 1998; and, Aluko, 2000).

Of recent, the number of distressed banks in the country had been on the increase from 7 in 1991 to figures as high as 60 and 57 in 1995 and 1996 respectively out of 115 banks. In the year 2002 alone, was an alarming num- ber of 35 out of which 5 were not only insolvent but terminally distressed (NDIC, 2002). Consequently, because of importance of valuations to property performance measurement and loan underwriting process, coupled with an increasing interest in property investment on the part of institutional investors and an increased exposure to property by the banking sector, a serious challenge is posed to estate surveyors and valuers in the country. Thus, the ability of valuers to make effective estimations of value, as obtained worlwide, has been subjected to intense scrutiny by academic, the media and the courts and, the apparent lack of a coherent and consistent result from the valuation process has damaged the reputation of the valuation profession (see for example, Greenwells \& Co., 1976; Hager and Lord, 1985; Smith, 1986, Brown, 1985; 1992; Cole, Guilkey and Miles, 1986; Ferguson, 1988; Lizieri and Venmore - Rowland, 1991; Cullen, 1994;

\section{International Journal of Strategic Property Management \\ ISSN 1648-715X \\ http://www.vtu.lt/english/editions}


Matysiak and Wang, 1995; Blundell, 1995; Adair, Hutchison, MacGregor and Nant-hakumaran, 1996; Ogunba, 1997; Ogunba and Ajayi, 1998; Parker, 1998, 1999; Graff and Young, 1999; Bowles, McAllister and Tarbert, 2001; Harvard, 2001 and Bretten and Wyatt, 2001). Nevertheless, of all the previous studies none has investigated the reliability of mortgage valuations for institutional lending in Nigeria. Besides, it is pertinent to observe also that these studies, apart from Ogunba (1997) and Ogunba and Ajayi (1998), adressed the problem of reliability of valuations in the context of British, Australian and American property valuations experience and empirical data. Even, the various empirical studies by Ajayi, 1990; 1992 and 1993 on the Nigerian mortgage market did not help as they are tangentially related to the issues at hand and, only isolated crucial factors which generally explain loan default and not the mortgage valuations process or reliability. The essence of this paper is to address the foregoing problem, with a view to improving the quality of mortgage valuations, as way of seeking policy solutions to the rampant collapse of banks in the country. The paper therefore aimed below at reviewing and considering the relevance, both qualitative and quantitative commentaries and analyses of valuation accuracy in overseas and local literature. In addition, prior to seeking to establish the reliability of mortgage valuations a sample survey of actual valuation and corresponding sales prices relating to mortgaged property are considered. Finally, conclusions are then drawn concerning the possible implications for Nigerian valuation practitioners, users of mortgage valuations and the local investment property market generally.

\section{VALUATION AND INSTITUTIONAL LENDING}

Valuation for mortgage is on the same principle as if for sale, since, the lender, in order to realise the security can take advantage of the power of sale. Central to this, property must be assumed to have been sold (with contracts unconditionally completed) for cash consideration in the open market at the date of valuation. The open market value (OMV) is intended to represent:

"the best price at which a sale of an interest in property might reasonably be expected to have been completed unconditionally for cash consideration on the date of valuation, assuming:

- a willing seller;

- that, prior to the date of valuation, there had been a reasonable period (having regard to the nature of the property and the state of the market) for the proper marketing of the interest, for the agreement of price and terms and for the completion of the sale;

- that the state of the market, level of values and other circumstances were, on any earlier assumed date of exchange of contracts, the same as on the date of valuation; and,

- that no account is taken of any additional bid by a purchaser with a special interest" RICS (2000).

The OMV establishes the upper limit above which the lender should not exceed in advancing loan. It enables the lender to evaluate the potential profitability or marketability and security of the mortgage investment as at the date of valuation. The OMV is also taken into consideration where the mortgagor is in default or distress and, the mortgaged property is to be disposed of in the open market to defray the debt owed.

But, the open market value is an indication of price at a point before the loan goes on risk and offers no guarantee that the price paid is achievable again in the future. Expectedly, following the downturn in the property market in the late 1980 s and the accompanied bad debts that arose on loan made during the boom, a joint working committee of Royal Institution of Chartered Surveyors RICS and British Bankers' Association (BBA) adopted new definitions of estimated realisation price ERP and 
-timated restricted realisation price (ERRP) to modify the existing open market valuation for bank lending (Loveli and French, 1996). The definition of ERP is stated thus: "an opinion as to the amount of cash consideration before deduction of costs of sale which the valuer considers on the date of valuation can reasonably be expected to be obtained on future completion of an unconditional sale of the interest in the subject property assuming:

- willing seller;

- that completion will take place on a future date specified by the valuer to allow a reasonable period, (having regard to the nature of the property and the state of the market), for the proper marketing;

- that no account is taken of any additional bid by a prospective purchaser with a special interest;

- that both parties to the transaction will act knowledgeable, prudently and without compulsion".

When producing an ERP, the valuer is required to consider how long, from the valuation date, would be reasonable to market the property properly and achieve the best price. If the client feels that the marketing period is in excess of what circumstances can allow, a variant of ERP can be used which assumes a shorter marketing period. This is called estimated restricted realisation price (ERRP) RICS 2000).

Notwithstanding the similarity between UK and Nigeria, being a colony of the former, the definitions of ERP and ERRP are yet to gain acceptance in Nigerian mortgage market. Most valuation reports still refer to OMV as the basis of advising banks on lending (Aluko, 2000). The former definition of OMV is therefore adopted in this paper in testing the reliability of mortgage valuation for institutional lending in the country.

\section{VALUATION UNCERTAINTY}

There is increasing institutional, legal and professional acceptance that valuation uncer- tainty exists and persuasive grounds to expect its presence (RICS, 1997; Bowles, McAllister and Tarbert, 2001). Values can be difficult to assess due to different concepts of value and the heterogeneity of property including the number of transactions that occur at prices that do not represent market values. This uncertainty in valuation can be decomposed into two forms (Brown, 1985; Parker, 1998; Harvard, 2001;) -valuation variance and valuation accuracy.

Valuation accuracy relates to error in valuation as the transaction prices of properties differ from their valuations. Transaction prices are viewed as "noisy" signals of true market values. And, it is argued that the imperfections of the property market mean that transaction price and true market value will rarely coincide. Nevertheless, if valuers are doing good job of price estimation, valuations should act as a good proxy for prices.

On the other hand, where different valuers place a different value on the same property, it does not necessarily imply inaccuracy. Rather, it implies imprecision or valuation variance. If a high degree of variance is exhibited, valuations will vary from valuer to valuer, thus the valuations produced by individual valuers cannot be assumed to be reliable. Specifically, this paper is on valuation accuracy and not valuation variance. The following related empirical studies are examined to ascertain the existence and identify the extent of valuation inaccuracy.

The debate on valuation accuracy can be traced to UK, where Hager and Lord (1985) conducted a small sample survey often valuers who were invited to value two properties, but, obtained answers which ranged from $£ 630,000$ to $£ 780,000$ for an office property and $£ 450,000$ to $£ 655,000$ for a shop property. The survey suggested a low level of valuation accuracy and questioned the ability of valuers to assess accurately the value of property. But, the initial responses were entirely defensive. For example, Brown (1985) using a sample of 29 properties, over the period 1975 to 1980 , and adopting regression model setting the 
transaction prices against, prior, independent valuations, found a close correspondence between value and price. Besides, Brown (1985) analysed 26 properties over a period between 1981 and 1984, using the same technique as Hager and Lord (1985), but, concluded that one firm's valuations were a good proxy for those of another. Similarly, Reid (1985) criticised the conclusions in Hager and Lord (1985) by questioning the information and instructions given to the valuers and the quality of their response given the absence of a fee.

Subsequently, Investment Property Databank in collaboration with Drivers Jonas (IPD/DJ, 1988) sampled 1, 442 properties sold between January, 1982 and March, 1988 and for which prior valuations carried out on an average of 9.7 months before the sale, were known. They concluded that the valuations were closely related to the sale prices. The study was updated to consider 2, 400 properties in 1990 in response to suggestions that the property market climate during 1982 and 1986 was unrepresentative, but, confirmed the earlier result suggesting a high level of valuation accuracy. Similar studies in UK by Cullen (1994) and Blundell (1995), using large representative data over an extensive period of time confirmed the conclusions in earlier studies of a high correlation between valuations and transaction prices.

However, Lizieri and Vemore - Rowland (1991; 1993) questioned the integrity of the findings of regression - based approaches of Brown (1985) and IPD/DJ (1988; 1990) concerning high levels of valuation accuracy and concluded that the statistical methodology was flawed. In a rejoinder to Lizieri and Vemore - Rowland, Brown (1992) argued that the criticism failed to consider the economic foundation of the valuation models and the importance of the information set. Therefore, their discussion was not a rejection of regression techniques for testing valuation accuracy. And, as observed by Adair, Hutchison, MacGregor, MacGreal and Nanthakumaran (1996) through the accumulation of large databases and analyses of infor- mation over time good results can be obtained from regression - based study.

Furthermore, Adair, Hutchison, MacGregor, McGreal and Nanthakumaran (1996) examined variations in valuations through a survey of valuers employed in both major national firms and local chartered surveying practices using standard deviation technique. Contrary to the earlier studies, they concluded that the survey showed a wide variation in value across both rack rented and reversionary interests. In terms of the former over $80 \%$ of all valuations produced a variation from the mean of less than $20 \%$ with a compounding figure of over $90 \%$ for the reversionary investments. These levels of accuracy fall short of the contention that valuers can value to within 5 to 10 percent of market value as opined by Mackmin (1985). They also observed lack of consistency in the approach to calculation of effective rents. Also, in recent study by Harvard (2001) on commercial valuation reliability and valuer behaviour in the UK, the findings revealed that the normal behaviour of valuers and the procedures followed by valuation firms lead to a high risk of an unsupportable valuation being reported to a client.

Expectedly, because of the volume of real estate activities and the roles of valuation practitioners in the UK as indicated above, it is not surprising that several studies above identified a high level of valuation accuracy, notwithstanding, few indicating lower levels. But, some of these studies are limited in application as none of the valuers who participated in the studies received any payment for the work carried out. This must raise a question as to whether the valuers would have taken greater care or researched the market more thoroughly had a fee been offered and their professional liability insurance been at stake. In addition, the market conditions in the UK, when the studies were conducted are not indicated, and, they may not be representative of normal market conditions.

Germane to the forgoing, Parker (1998) who analysed valuation accuracy in Australia as 
indicative of a high correlation between valuations and market prices, using case study and a small sample, opined in respect of the studies above that they are marred by the emphasis on statistical analysis at the expense of a focus on the underlying flaws in approach. According to him, the use of hypothetical properties, non-contemporaneous valuations and transactions and large data sets which may mask the potentially significant differences at the individual property level are each indicative of the basic flaws in the analyses upon which the interminable statistical quibbling merely builds. He, however, contrary to the view above, admitted that given the small sample size for the case study, it would be inappropriate to have too much regard to his finding. It therefore helps to reaffirm that large data sets and the statistical techniques - particularly, regression models, are required for the studies to be representative of the market conditions and valuation practice in the UK.

In the United States (US), Cole, Guilkey and Miles (1986) measured the reliability of one group of commercial appraisals by comparing the value judgement of appraisers to actual sales prices. They claimed the overall results did not indicate a high degree of reliability in the individual commercial appraisal product. And, Ferguson (1988) discovered evidence that under certain conditions, such as availability of adequate information among market participants, residential appraisal values are correlated with contract prices. In addition to the above studies, Plattner (1990) reported on two studies of appraised values to sale prices for real estate holding of a large insurance company pension fund. The first study, which involved 294 properties sold from 1973 to 1987 , indicated that the appraised values were on average $50 \%$ below sales prices during the 14-year period. A similar second study using data from 52 properties sold from 1973 to 1981 concluded that appraised values were $7 \%$ below sales prices during that period. Two possible explanations were given for the variance:

First, the manager of the real estate port- folio offered the explanation that his firm was regularly able to obtain "above market" prices from buyers and, a second suggestion indicated that in many markets, foreign buyers were willing to pay higher than market prices for properties. It is to be noted that neither of these explanations explained the difference in value. A number of enquiries could be made. For instance, since the appraised value was based on market data and since sales represented market data, could some other forces have been at work which caused the discrepancies? No data were given as to the appraised dates and sales. Could market values have changed during the intervening period? Perceived values often change rapidly in response to the feeling and expectations of buyers and sellers. The reported statistics were based on the average variance. No indication was given on the range of variation or other measures of dispersion.

In Nigeria, Ogunba (1997) examined the correspondence between the valuations prepared on two residential properties by 30 different valuers using regression analysis and concluded that valuations prepared by one firm were a good proxy for valuations prepared by another firm. And, another study by Ogunba and Ajayi (1998), using the same technique, data size, the same period of study and methodology reached a contrary result. The results of the latter do not inspire confidence that valuers would produce accurate valuations in the country. Also, notwithstanding the contradictory conclusions, the two studies revealed that none of the valuers sampled inspected the properties before expressing their opinions of value. Failure to inspect these properties will restrict the amount of available information, as it will affect access to a database concerning comparable market transactions and investment yields. In addition, the approach adopted are susceptible to sample bias/error since valuers engaged are aware of the end result of the studies. The results of Ogunba (1997) and Ogunba and Ajayi (1998), in the light of the forgoing, have to be cautiously interpreted or 
accepted. The essence of this paper is to resolve the conflicting and unsupportable views above.

Moreover, examining all the empirical studies above revealed that valuers, despite the anecdotal evidence to the contrary, are doing a very good job of price estimation and, that valuations are a very good proxy for prices. They however, misses a fundamental point, which this paper aimed at correcting, that inaccuracy can only be assessed by observing differences between valuations and market prices and, not valuations and valuations by different valuers for the same property which implies variance or imprecision. However, the level of valuation accuracy in the country is observed in this paper, and, the implications are considered for the users of valuation services and the valuation profession.

\section{METHODOLOGY}

The paper examined whether the open market valuations act as a good proxy for prices in metropolitan Lagos, the study area. The study area, the former nation's capital territory, apart from being a commercial nerve centre of the country, harbours the headquarters and main branches of most of the financial institutions and estate surveying and valuation firms in the country Out of total population of 107 lending institutions and 146 estate surveying and valuation firms in the study area, 42 lending institutions and 59 estate surveying and valuation firms were interviewed. The initial plan of $50 \%$ of both respondent samples failed because of non-cooperative attitudes of some organisations due to the confidential nature of both lending decisions and valuation and property transactions. The respondents were, however stratified along location, age of establishment, number of employees and banking types and, were randomly selected to ensure adequate coverage and enhance accuracy of results. Information on the population of the respondent samples were obtained from the Nigerian Deposit Insurance Corporation (NDIC), Central
Bank of Nigeria $(\mathrm{CBN})$, The Nigerian Institution of Estate Surveyors and Valuers (NIESV), Estate Surveyors and Valuers Registration Board of Nigeria (ESVARBON) and the 2002 edition of Nigeria Banking Finance and Commerce Directory.

Following Brown (1985) and the insistence (see Brown, 1991; 1992; Ogunba and Ajayi; 1998) on the validity of multiple regression model in testing valuation accuracy or reliability despite Lizeiri and Venmore-Rowland's (1991) comment, the method was employed in processing data for this paper. The methodology involved regressing the open market value for mortgage of each of the properties sampled onto its transaction price. This can be expressed as

$$
\mathrm{V}=\mathrm{a}_{0}+\mathrm{a}_{1} \mathrm{P}+\mathrm{e} \ldots
$$

where $\mathrm{V}$ and $\mathrm{P}$ relate to the valuation and price and $\mathrm{a}_{0}$ and $a_{1}$ are the regression co-efficients. The final form e represents the error in the model not explained by the regression. The F-Ratio shows whether or not the independent variables have significant effects on the mean of the dependent variable. On the other hand, the $R^{2}$ provides a quantitative measure of how well the combination of independent variables predicts the dependent variable.

Although, the model above is more representative of the underlying economic conditions and valuation process, in order to cross-check and confirm the test in equation (1) above, a reversed procedure, as employed by Jonas/IPD (1988; 1990) using the model, as indicated in equation (2) below, was adopted. It is given as

$$
\mathrm{P}=\mathrm{a}_{0}+\mathrm{a}_{1} \mathrm{~V}+\mathrm{e} \ldots
$$

The variables are as defined in equation (1) above.

To test mortgage valuation reliability using the two models above, pooled data of 121 open market sales relating to transactions on mortgaged residential properties during the period January, 1994 to December, 2002 were obtained from the NDIC, lending institutions and estate surveying and valuation firms in the study area. Upon a mortgagor being unable to redeem his 
financial obligation to the lender, an open market valuation before a sale of the collateral security is ordered before an advantage of sale is taken. The valuation is carried out on the same basis as mortgage valuation executed before a loan is advanced. The data collated include open market values and transaction prices of mortgaged properties sold in the study area during the period mentioned above. The date of the valuation and the date of the sale for each property transaction were, almost, exactly contemporaneous, with an interval of not exceeding one month between the two dates in all the transactions. In addition, the transaction properties sampled have good and marketable titles, none below 70years duration; are free from all onerous restrictions and charges; and, are not affected by, or subject to compulsory acquisition, road widening, new road proposals or planning regulations. Given the foregoing conditions, the study has avoided the shortcoming and limitations of regression model observed by Lizieri and VenmoreRowland (1991) in testing valuation accuracy. But, a mortgage valuation is deemed to be reliable only if there is one to one correspondence between valuations and prices. In particular, we tested whether the slope (a) in the equations above is close to 1.0 and is statistically significant. The time frame for the study 1994 - 2002) is a period of economic recession $\mathrm{m}$ the country, but, as indicated in the previous studies reviewed above, and, given the different value concepts and the imperfection of the trading environment including property market structures, no appreciable difference in results may be noted, notwithstanding, whether or not normal, boom or recession exists.

Table 1. Regression Result on Open Market Values versus Prices (1994-2002)

\section{RESULTS AND DISCUSSION}

In line with the objective of the paper, the following represents the overall results synt-hesised from the empirical study analysed (table 1).

Given the results in table 1 below, the regression equation obtained for our samples become:

$$
\mathrm{V}=6.2932+0.5774 \mathrm{P} \ldots
$$

As shown on the table the relationship between the values and the prices of the properties sampled is $78 \%$ and it is significant at $\mathrm{P}$ equals $\mathbf{0 . 0 0 0 0}$. In addition, since $\mathbf{R}^{\mathbf{2}}=\mathbf{0 . 6 1}$, it indicates that prices of those properties accounted for $\mathbf{6 1 \%}$ of inaccuracy in their values.

For a test of valuation accuracy, the slope of the equation $\left(\mathbf{a}_{1}\right)$ must be very close to $\mathbf{1}$ and statistically significant while the intercept $\left(\mathbf{a}_{\mathbf{0}}\right)$ should not be statistically distinguishable from zero. The equation (3) above appears to have confirmed that there is one-to-one relationship. The slope $\left(\mathbf{a}_{1}\right)$, which is $\mathbf{0 . 5 7 7 4}$, in this case, is statistically indistinguishable from 1.0; although, the relationship is not as perfect as it would have been expected to be. But, the intercept $\left(\mathbf{a}_{\mathbf{0}}\right)$, obtained as $\mathbf{6 . 2 9 3 2}$, is significantly different from zero. A number of plausible reasons can be adduced for this situation. It may be because it is not impossible for the timing of valuations and prices not to be exactly contemporaneous. Also, given the different value concepts and the imperfection of the trading environment and market structure, occasioning different interpretation of market data by valuers, market data availability and reliability problem, adoption of different bases

\begin{tabular}{|c|c|c|c|c|c|c|c|}
\hline \multirow[t]{2}{*}{ Equation } & \multicolumn{2}{|c|}{ Independent Variables } & \multirow[t]{2}{*}{$\mathbf{R}$} & \multirow[t]{2}{*}{$\mathrm{R}^{2}$} & \multirow[t]{2}{*}{ Adjusted $\mathrm{R}^{2}$} & \multirow{2}{*}{$\begin{array}{l}\text { Standard } \\
\text { Error }\end{array}$} & \multirow[t]{2}{*}{ F-Test } \\
\hline & $a_{0}$ & $a_{1}$ & & & & & \\
\hline 3 & 6.2932 & 0.5774 & 0.78147 & 0.61069 & 0.61053 & 8.28873 & 0.0000 \\
\hline
\end{tabular}

Source: Field Survey and Analysis (2002) 
and techniques of valuation for the same purpose, etc, it would be unreasonable to expect valuers to predict transaction price either precisely or exactly accurately. This condition obtains whether or not normal boom or recession predominates in the market.

Notwithstanding the foregoing, the high $\mathbf{R}^{2}$ value shows that prices explain about $61 \%$ of their equivalent valuations. Thus, we can conclude on the evidence of regression analysis that there is a relative degree of accuracy in the open market valuations for mortgage. Therefore, open market valuations of mortgaged properties are good proxies for their market prices.

The statistical test above has further confirmed the results of the regression equation obtained in the earlier research by Brown (1985) as:

$$
\mathrm{V}=0.20+1.02 \mathrm{P}\left(\mathrm{R}^{2}=0.99\right) \ldots
$$

Although, in both cases, valuations were a good proxy for prices, it is, however, significant to note that the degree of accuracy of valuations in interpreting market prices bahaviour in the UK is higher than that which obtains in Nigeria as reflected in the difference in the $\mathrm{R}^{2}$. This is not unexpected given the relatively higher level of information availability and documentation in the UK. Nevertheless, when the results in table 1 are compared with the regression equation obtained by Ogunba (1997) and Ogunba and Ajayi (1998) on Lagos property market, which is expressed as:

$$
\mathrm{V}=27.12+1.2785 \mathrm{P}\left(\mathrm{R}=0.49 ; \mathrm{R}^{2}=0.242\right) \ldots(5)
$$

There is a sharp contrast in the conclusions emanating from these studies in relation to the current one. The previous studies have to be cautiously interpreted, as they appear inconclusive because the sample size is too small for such overreaching results and the properties sampled were not inspected by the respondent valuers before expressing opinion of values. Thus, the information set available to the valuers may not be the same. In addition, the valuations were undertaken after the sale of the properties sampled had taken place thereby introducing element of bias in the valuation process. A better approach should have been to gather sample of properties, each having both a transaction price and a contemporaneous independent valuation.

\subsection{Prices versus Open Market Values}

Unlike the equation 1 above, a reversed procedure adopted by Drivers Jonas/IPD (1988; 1990), as shown in equation 2 above, were used to explain variation in price in terms of valuation. The reversed model is reproduced below:

$$
\mathrm{P}=\mathrm{a}_{0}+\mathrm{a}_{1} \mathrm{~V}+\mathrm{e} \ldots
$$

The variables are as explained in equations 1 and 2 already discussed above.

Adopting the reversed model and regressing prices onto the valuation the following results were obtained as presented in Table 2 below.

From the Table 2 below, equation 7 is given as follows:

$$
P--9.7807+1.6683 V\left(R^{2}=0.6294\right) \ldots
$$

The equation above indicates that the relationship between the prices and values of the properties sampled is $79 \%$ and it is significant at $\mathrm{P}$ equals 0.0000. Besides, since $\mathbf{R}^{\mathbf{2}}=\mathbf{0 . 6 2 9}$, it reveals that

\begin{tabular}{|c|c|c|c|c|c|c|c|}
\hline \multirow[t]{2}{*}{ Equation } & Indepen & ariables & \multirow[t]{2}{*}{ R } & \multirow[t]{2}{*}{$\mathrm{R}^{2}$} & \multirow[t]{2}{*}{ Adjusted $R^{2}$} & \multirow{2}{*}{$\begin{array}{l}\text { Standard } \\
\text { Error }\end{array}$} & \multirow[t]{2}{*}{ F-Test } \\
\hline & $a_{0}$ & $a_{1}$ & & & & & \\
\hline 7 & $-9,7807$ & 1.6683 & 0.79341 & 0.62949 & 0.62521 & 14.0889 & 0.0000 \\
\hline
\end{tabular}
values of those properties accounted for $\mathbf{6 2 . 9 \%}$ of variation in their prices.

Table 2. Regression Results on Prices V Open Market Values (1994-2002)

Source: Field Survey and Analysis (2002) 
These results signify that prices were a good proxy for valuations. The intercept $\left(\mathrm{a}_{0}\right)$, which is 9.7808 in this case, is not significantly different from zero. However, the slope co-efficient $\left(\mathrm{a}_{1}\right)$ is above 1 but the high $\mathrm{R}^{2}$ of $62.9 \%$ confirms the findings of the previous results in table 1 above. The results of the slope and intercept might be unconnected with some of the reasons already adduced in table 1 above. But, if the latter equations are compared with the regression equation obtained by Drivers Jonas/IPD (1988; 1990) using a sample of 1442 properties within the IPD database expressed as follows:

$$
\mathrm{P}=3.56+1.061 \mathrm{~V}\left(\mathrm{R}^{2}=0.93\right) \ldots
$$

The results show a slope co-efficient (1.061) which is close to 1.0 thereby confirming the findings in table 1 and 2 above. The intercept term $\left(\mathrm{a}_{0}\right)$, notwithstanding, the analyses above shows that there is a reasonable likelihood that the open market value advice given by valuers $m$ the country could be a good guide or indicator of the market transaction price. Perhaps, the valuation can, therefore, assist in determining the marketability of mortgaged properties as well as help to reach a meaningful decision in the loan underwriting process. But, it has to be noted that valuers in Nigeria are not interpreting their markets with anything close to the accuracy of valuers in Britain as already explained above. This is confirmed from the equation 8 above with $\mathrm{R}^{2}$ of 0.93 .

\section{CONCLUSIONS}

Empirical evidence above suggests that estate surveyors and valuers in the country are doing a very good job of price estimation through open market valuations for mortgage. However, they are not interpreting their mar-sets with degree of reliability, which obtains in Britain. The implication is that there is still room for improvement in the discharge of valuation function. This might not be unconnected with interpretative errors, unreliable of faulty assumptions, adoption of unverified data, basis and mortgage method (s) of valuation. Unreliable valuations may constrain property performance analysis, adversely influence the relevance and credibility of the valuer, and, have damaging confidence in the property market as well as the operation of property indices. The role of valuation for mortgage is, then, put at risk, as the lending institutions might be unable to recoup the delinquent loans from the mortgaged properties. Thus, users of mortgage valuations may be forced to patronise other professionals like bankers, actuaries, accountants, etc as better substitutes in providing valuation advice. This, probably, explains why Engineers and Quantity Surveyors in the country are currently challenging and claiming expertise in the domestic domain of valuers.

It is the responsibility of the valuation profession to ensure that uncertainty in mortgage valuation is minimised in order to provide more meaningful valuation advice. Perhaps, the way forward could be through the availability of centralised data base to which all valuers would have access, Continuing Professional Development (CPD) by way of workshops, seminars, conferences, etc and, the need to update the 1985 valuation standards published by The Nigerian Institution of Estate Surveyors and Valuers (NIESV). Stricter guidelines, as internal control mechanism, are required for uniformity sake and to reduce the likelihood of external pressure and the adoption of quality assurance systems in the workplace can help maintain acceptable standards.

Again, the evidence suggests that property valuation is a snapshot in time. The estimate of price in the market today (OMV) will not necessarily be the same as it will be at some future date. In the content of bank lending, such a difference in time may have a significant impact on the lending decision. Therefore, for mortgage valuations to be forward-looking, it requires an indication of the likely future selling price. The new valuation concepts-estimated realisation price (ERP) and estimated restricted realisation price (ERRP), as obtainable in the UK may be adopted in the country. 
The new definitions moves the marketing period, as assumed in OMV, from prior to the valuation date to a reasonable period running from it, the duration of the marketing period being determined by the valuer.

Against the backdrop of the implications and, consequently, the recommendations above, the paper may help in seeking policy solutions to the rampant collapse of banking institutions as valuation is an important input in loan or mortgage underwriting process. Further research on the issues raised above and valuation techniques, including behavioural concepts that affect the market's search and price setting process could help to improve the reliability of mortgage valuations in the country. However, given the trading environment and market structures, whether or not, recession, boom or stability exists, in the property market, it would be unreasonable to expect valuers to predict transaction price either precisely or exactly accurately.

\section{REFERENCES}

Adair, A., Hutchison, N., MacGregor, B., McGreal, S. and Nanthakuman, N. (1996) An Analysis of Valuation Variation in the UK Commercial Property Market. Property Valuation and Investment, 14(5), p. 34-47.

Ajayi, C.A. (1990) An Analysis of Default Factors in the Residential Mortgages of the Federal Mortgage Bank of Nigeria and Oyo State Property Development Corporation, an Unpublished Ph.D Thesis, Obafemi Awolowo University, IleIfe.

Ajayi C.A. (1992) An Analysis of Default Factors in Residential Mortgages of the Federal Mortgage Bank of Nigeria. African Review of Money F $i$ nance and Banking, 2, p. 203-216.

Ajayi C.A. (1993) Residential Mortgage Delinquency and Foreclosure in Oyo State Property Development Corporation, Nigeria: A Discriminant Function Analysis. Savings and Development, XVIK3), p. 309-318.

Aluko, B.T. (2000) A Study of the Appropriateness of Mortgage Valuation for Institutional Lending in Nigeria, an Unpublished Ph.D Thesis, Obafemi Awolowo University, Ile-Ife.
Baum, AE. (1998) "Forward", in Ajayi, C.A. (1998), Property Investment Valuation and Analysis, DeAyo Publications, Ibadan, pp. VII-LX.

Blundell, G. (1995) Investment in Property: A Victim of the Quants? The Actuary, October, pp. 12-13.

Bowles, G., McAllister, P., and Tarbert, H. (2001) An Assessment of the Impact of Valuation Error on Property Investment Performance Measurement. Journal of Property Investment and Finance, 19(2), p. 139-155.

Bretten, J. and Wyatt, P. (2001) Variance in Commercial Property Valuations for Lending Purposes: An Empirical Study. Journal of Property Investment and Finance, 19(3), p. 267-282.

Brown, G.R. (1985) Property Investment and Performance Measurement: A Reply. Journal of Property Valuation and Investment, 4(1), p. 3344.

Brown, G.R. (1992) Valuation Accuracy: Developing the Economic Issues. Journal of Property Research, 9, p. 199-207.

Cole, R., Guilkey, D and Miles, M. (1986) Toward an Assessment of the Reliability of Commercial Appraisals. The Appraisal Journal, July, p. 5358.

Crosby, N., French, N. and Ward, C (1993) Valuation Accuracy: A Self-fulfilling Prophecy, Being a Research Proposal Presented at the Royal Institution of Chartered Surveyors Conference The Cutting Edge", $2^{\text {nd }}$ April, 12 p.

Cullen, I. (1994) The Accuracy of Valuations Revisited, The Cutting Edge 1994, The Royal Institution of Chartered Surveyors, London, pp. 91101.

Ferguson, J.T (1988) After-sale Evaluations: Appraisals or Justifications. The Journal of Real Estate Research, 3(1) (Spring) p. 19-26.

Graff, R.A and Young, M.S. (1999) The Magnitude of Random Appraisal Error in Commercial Real Estate Valuation. Journal of Real Estate Research, 17(1/2), p. 33-54.

Greenwell, W. and Co. (1976) A Call for New Valuation Methods. Estates Gazette, 238(5780), p. 481-484.

Hager, D.P. and Lord, D.J. (1985) The Property Market, Property Valuations and Property Performance Measurement, Institute of Actuaries, London.

Harvard, T (2001) Valuation Reliability and Valuer Behaviour. Research Paper, 4(1), RICS, London, $46 \mathrm{p}$. 
IPD/DJ (1988) The Variance in Valuations, Investment Property Databank/Drivers Jonas, London.

IPD/DJ (1990) The Variance in Valuations, Investment Property Databank/Drivers Jonas, London.

Lizieri, C, and Venmore-Rowland, P. (1991) Valuation accuracy: A contribution to the debate. Journal of Property Research, 8, p. 115-122.

Lizieri, C, and Venmore-Rowland, P. (1993) Valuations, Prices and the Market: A Rejoinder. Journal of Property Research, 10, p. 77-84.

Loveli, R. and French, N. (1996) Estimated Realisation Price: What do the Banks want and what can Realistically be Provided? Journal of Property Finance, 6(4), p. 7-16.

Macmin, D.H. (1985) Is there a Residential Valuer in the House? Journal of Valuation, 3(4), p. 384390.

Matysiak, G.A. and Wang, P. (1995) Commercial Property Market Prices and Valuations: Analysing the Correspondence. Journal of Property Research, 12, p. 181-202.

McWilliams, D. (1992) Commercial Property and Company Borrowing, The Royal Institution of Chartered Surveyors, London.

NDIC (2002) Annual Reports, NDIC, Lagos.

NIESV (1985) Property Valuation Standards and Guidance Notes, NIESV, Lagos

Ogunba, O.A (1997) A Study of Valuation and Pricing Practices in the Residential Property Market in Lagos Metropolis, an Unpublished M.Sc. Thesis, Obafemi Awolowo University, Ile-Ife.
Ogunba, O.A. and Ajayi, CA. (1998) An Assessment of the Accuracy of Valuations in the Residential Property Market of Lagos. The Estate Surveyor and Valuer, 21(2), July, p. 19-13.

Parker, D.R.R. (1998) Valuation Accuracy - an Australian Perspective, $4^{\text {th }}$ Pacific Rim Real Estate Society Conference, Perth, 19-21 January, 19 p.

Parker, D.R.R. (1999) A Note on Valuation Accuarcy: an Australian Case Study. Journal of Property Investment and Finance, 17(4), p. 401-411.

Plattner, R.H. (1990) A Critique of Recent Appraisal Practice. The Appraisal Journal, April, p. 180189.

Reid, I. (1985) Response to Hager and Lord. Estates Gazette, 274, p. 19-21.

RICS (1997) Commercial Investment Property: Valuation Methods - an Information Paper, RICS, London.

RICS (2000) Appraisal and Valuation Manual (the "Red Book"), March 2000 update, RISC, London.

Smith, H.C. (1986) Inconsistencies in Appraisal Theory and Practice. The Journal of Real Estate Research, 1(1) (fall), p. 1-17.

Trott, A. (1980) Property Valuation Methods: Interim Report, Polytechnic of the South Bank/ Royal Institution of Chartered Surveyors, London.

Trott, A. (1986) ed., Property Valuation Methods: Interim Report, Polytechnic of the South Bank/ Royal Institution of Chartered Surveyors, London. 